\title{
Review \\ Review of Professionally Applied Fluorides for Preventing Dental Caries in Children and Adolescents
}

\author{
Aneta Munteanu ${ }^{1}$ (D), Alina-Maria Holban ${ }^{2,3}$, Mihaela-Rodica Păuna ${ }^{4}$, Marina Imre ${ }^{4, *}$, \\ Alexandru-Titus Farcașiu ${ }^{4, *(D)}$ and Cătălina Farcașiu ${ }^{1}$
}

1 Department of Pediatric Dentistry, Faculty of Dental Medicine, "Carol Davila" University of Medicine and Pharmacy, 032799 Bucharest, Romania; aneta.munteanu@umfcd.ro (A.M.); catalina.farcasiu@umfcd.ro (C.F.)

2 Microbiology \& Immunology Department, Faculty of Biology, University of Bucharest, 77206 Bucharest, Romania; alina.m.holban@bio.unibuc.ro

3 Research Institute of the University of Bucharest-ICUB, University of Bucharest, 050657 Bucharest, Romania

4 Department of Prosthodontics, Faculty of Dental Medicine, "Carol Davila" University of Medicine and Pharmacy, 032799 Bucharest, Romania; mihaela.pauna@umfcd.ro

* Correspondence: marina.imre@umfcd.ro (M.I.); alexandru.farcasiu@umfcd.ro (A.-T.F.)

check for

updates

Citation: Munteanu, A.; Holban,

A.-M.; Păuna, M.-R.; Imre, M.;

Farcașiu, A.-T.; Farcașiu, C. Review of

Professionally Applied Fluorides for

Preventing Dental Caries in Children

and Adolescents. Appl. Sci. 2022, 12,

1054. https://doi.org/10.3390/

app12031054

Academic Editors: Paola Gandini and

Andrea Scribante

Received: 20 December 2021

Accepted: 17 January 2022

Published: 20 January 2022

Publisher's Note: MDPI stays neutral with regard to jurisdictional claims in published maps and institutional affiliations.

Copyright: (C) 2022 by the authors. Licensee MDPI, Basel, Switzerland. This article is an open access article distributed under the terms and conditions of the Creative Commons Attribution (CC BY) license (https:// creativecommons.org/licenses/by/ $4.0 /)$.

\begin{abstract}
This review aims to evaluate the effectiveness of professional topical fluoride application on the prevention of dental caries in primary and permanent dentition. A web search was conducted for English papers published from 2000 to 2020, using various digital resources (Pubmed, Google Scholar, Cochrane Library, and ResearchGate). The keywords were "professionally applied fluoride", "fluoride gel", "fluoride varnish", "fluoride foam", "fluoride mouthrinses", and "non-cavitated caries lesions". Inclusion criteria: (a) participants: children and adolescents, treated in a dental care setting; (b) intervention: professionally applied fluorides (gel, varnish, foam, mouthrinse); (c) comparator: no professional treatment or other preventive treatments; (d) outcomes: clinical effectiveness (e.g., caries reduction, tooth remineralization); (e) study design: randomized controlled trials, systematic reviews, meta-analyses; (f) publication period: 1 January 2000-31 December 2021. Clinical studies about home-use fluoride products, discussion papers, in-vitro studies, case reports, non-English articles, and studies with unclear methodology were excluded. Topical fluoride applications are indicated for patients with active smooth surface caries and for patients in high caries risk groups. Both APF gel and fluoride varnish are effective and can be recommended for caries prevention in primary and permanent teeth. For children under the age of 6 , only $2.26 \%$ fluoride varnish is recommended.
\end{abstract}

Keywords: fluorides; professional application; caries prevention; children; dentistry; pedodontics; review

\section{Introduction}

Dental decay is considered a very important oral health problem because it is a multifactorial oral disease that affects hundreds of millions of people throughout the world [1]. A decline in caries prevalence has occurred in most advanced countries since 1970; however, dental caries is the most common chronic disease in the world, affecting between $60 \%$ and $90 \%$ of school children and the majority of adults [2].

Factors involved in caries etiology are cariogenic bacteria, fermentable dietary sugars, and susceptible tooth surfaces. The activity of cariogenic bacteria involves the formation of organic acid that can contribute to the solubilization of minerals (e.g., calcium, phosphate) from the tooth surface (demineralization) [2,3]. Under favorable conditions, a reversal phenomenon with a mineral gain is possible (remineralization). If the demineralization process prevails, visually detectable caries lesions occur. The caries disease process is dynamic; it may progress, stop, or even reverse. The proper assessment of the grade and activity of the caries lesion is challenging [3].

Early signs of caries consist of non-cavitated carious lesions (i.e., initial or white spot lesions). If the carious lesion is not controlled, further loss of teeth minerals occurs 
and leads to a cavitated lesion [2]. Early detection, proper diagnosis, and the use of effective remineralization therapies (e.g., fluorides) are essential for the management of non-cavitated carious lesions [2]. Fluoride has been considered a very important factor in the decrease in the prevalence and severity of dental caries in developed countries [4].

Fluoride has a long-term relationship with dental practice and preventive dentistry; documents older than 200 years refer to the probable link between fluoride and carious activity [5]. Future research seems to aim for improving the antimicrobial and anti-degradative properties of current restoration materials [6], associated with the modification of their composition in order to reduce microbial attachment and biofilm formation [7].

Fluoride can be delivered topically and systemically. Topically applied modalities can be divided into self-applied and professionally applied topical fluorides. Self-applied fluorides are typically for home use: toothpastes, mouth rinses, and gels. Home-use dental products in the European Union have a maximum concentration of 1500 ppm $(1500 \mathrm{mg} / \mathrm{kg})$ for adults and children older than 6 years, while for younger children, the upper limit is 1000 ppm [8].

The quantity of systematically available fluoride depends on the percentage of toothpaste swallowed per application [9]. Immediate intoxication is very rare as the toxic dose is $5 \mathrm{mg} / \mathrm{kg}$ [10]. Children younger than 6 do not have a well-controlled swallowing reflex; fluoride being ingested in age-dependent proportions (65\% in 2-year-olds, $50 \%$ in 4 -yearolds, and 34\% in 5-year-olds) [10] requires more parental control on ingested fluoride in order to reduce the development of fluorotic lesions in the upper incisors [11]. Adults swallow around $10 \%$ of the quantity used for tooth-brushing [9]. Serious systemic toxicity and fatalities following acute exposure to fluoride are rare, but toxic signs of overexposure are not so rare with gastric signs and symptoms prevailing [12].

The overdose in adults is more likely to happen in regions with high levels of fluoride in tap water rather than in regions with artificially fluoridated water, while for children the risk increases for younger ages due to swallowed toothpaste [9].

The occurrence and severity of dental fluorosis depend on the parameters of fluoride exposure (dose, duration, timing) during the period of enamel formation [13]. Some studies showed that there is a higher risk for dental fluorosis if an excessive quantity of fluoride is environmentally present during the first two years of life, regarded as a critical period of greater susceptibility [14]. Therefore, the risk of dental fluorosis following professionally topical applied fluoride is low.

Limited scientific evidence showed a decrease in the odds ( $\mathrm{OR}=0.66$ [0.48-0.90] or no statistically significant difference OR $=0.92$ [0.71-1.18], 95\% CI) of having fluorosis when fluoride toothpaste use was started after 24 months. Beginning to use fluoride toothpaste after 12-14 months decreased the risk of fluorosis (OR $=0.70$ [0.57-0.88]), thus emphasizing the importance of using the appropriate amount of fluoride toothpaste in children [15].

There are self-applied gel formulations of sodium fluoride (1.1\% [5000 ppm] sodium fluoride) or stannous fluoride $(0.15 \%$ [1000 $\mathrm{ppm}]$ fluoride) available by prescription for home use [16].

Professionally applied topical fluorides are used by a dental professional in the dental office, and they could be in the form of a gel, varnish, foam, or mouthrinse [17]. These products have a much higher fluoride concentration than self-applied fluorides and have usage restrictions for legislative reasons [18].

Professionally applied fluoride therapy is relatively inexpensive and easy to apply. Dentists have used topical fluorides for a long time to protect the oral health of children and adults, particularly for patients at greater risk [18]. Several factors may increase the caries risk for children and adolescents: poor oral hygiene, active caries, existing restorations, tooth enamel defects, eating disorders, lack of regular professional dental care, active orthodontic treatment associated with poor oral hygiene, high levels of Streptococcus mutans, poor diet, undergoing head and neck radiation therapy, abuse of drugs or alcohol, and dry mouth (xerostomia) [18]. 
Fluoride acts in several ways to protect against tooth decay. As a topical mode of action, low concentrations of fluoride in dental biofilm and saliva inhibit the dissolution of hydroxyapatite crystals and enhance the remineralization of damaged ones. In addition, fluoride reduces the acid production in dental plaque by interfering with the metabolic activity of various bacterial strains that produce acids $[19,20]$.

High levels of fluoride resulting from the topical fluoride application produce a temporary layer of calcium fluoride-like material on the enamel surface that acts as a fluoride reservoir. The fluoride is released slowly, particularly during acidic episodes produced by cariogenic bacteria, and becomes available to remineralize enamel or to interfere with the bacterial metabolism [17].

This review evaluated the effectiveness of professional topical fluoride application on the prevention of dental caries in primary and permanent dentition.

\section{Materials and Methods}

This paper aimed to examine and summarize the results of controlled clinical trials, systematic reviews, and meta-analyses regarding professionally applied fluoride for the prevention of dental caries in children and adolescents. A web search was conducted for English papers published between 2000 and 2021, using different digital resources (Pubmed, Google Scholar, Cochrane Library, and ResearchGate). The keywords used were "professionally applied fluoride", "fluoride gel", "fluoride varnish", "fluoride foam", "fluoride mouthrinses", and "non-cavitated caries lesions", refined through hand-search.

Inclusion criteria:

- Participants: children and adolescents, treated in a dental care setting;

- Intervention: professionally applied fluorides (gel, varnish, foam, mouthrinse);

- Comparator: no professional treatment or other preventive treatments;

- Outcomes: clinical effectiveness (e.g., caries reduction, tooth remineralization);

- Study design: randomized controlled trials, systematic reviews, meta-analyses;

- Publication period: 1 January 2000-31 December 2021.

Exclusion criteria: clinical studies about home-use fluoride products, discussion papers, in-vitro studies, case reports, non-English articles, and studies with unclear methodology.

This study is based on data from previously published literature and publicly available information. Therefore, the study did not require ethics approval and was conducted according to the principles of the Declaration of Helsinki.

Some reviews and meta-analyses measure the effect of the selected methods using preventive fraction (PF). PF is a percentual ratio computed as the difference between increment or prevalence in the control sample and study sample divided by the increment or prevalence in the control sample.

\section{Results and Discussions}

\subsection{Fluoride Gels}

The most widely used fluoride gels are: acidulated phosphate fluoride (APF) with $1.23 \%(12,300 \mathrm{ppm})$ fluoride ion and $2 \%$ sodium fluoride $(\mathrm{NaF})$ with $0.90 \%$ (9050 ppm) fluoride ion [16,17]. An early study conducted by Brudevold et al. [21] showed that an acidic environment increases the fluoride intake by enamel, justifying the highly acidic formulation ( $\mathrm{pH}$ of approximately 3.0) of fluoride gels [22].

Regular use of professionally applied fluoride gel is likely beneficial only for persons at high caries risk, especially those who do not live in areas with fluoridated water or do not brush their teeth daily with fluoride toothpaste [17].

Typically, fluoride gel application consists of using a gel loaded tray held in the mouth for $4 \mathrm{~min}$. There is a $30 \mathrm{~min}$ restriction for rinsing, eating, and drinking after the treatment to allow the teeth to absorb the fluoride and help repair the existing lesion with less soluble minerals [16,17].

The most common adverse effect of fluoride gel application is over ingestion manifested by nausea and vomiting. This can be prevented by seating the patient upright, 
not overfilling trays (no more than $2-2.5$ g per tray or $40 \%$ of tray's volume), by using well-fitted or custom trays, by the use of a suction device, and by separate insertion of upper and lower trays. Moreover, gagging may occur in young children, or they may find the experience unpleasant [23].

Studies showed that the use of professionally applied fluoride gel has a low risk for dental fluorosis, even among children under the age of 6, because it is applied by a dental professional relatively infrequently, from once a year to four times a year [17,22].

Marinho et al. (2015) performed a meta-analysis on self-applied and professionally applied fluoride gel: 25 trials (8479 participants) on permanent teeth and 3 trials (1254 participants) on primary teeth. The D(M)FS preventive fraction on average was $17 \%$ (95\% CI $3 \%$ to $31 \% ; p=0.018$ ) greater in non-placebo-controlled trials (the decline in caries was $38 \%$ (95\% CI $24 \%$ to $52 \%$; $p<0.0001,2808$ participants) for the 10 trials with no treatment as a control group, and $21 \%$ (95\% CI 15\% to $28 \% ; p<0.0001,5671$ participants) for the 15 placebo-controlled trials. The $\mathrm{d}(\mathrm{e} / \mathrm{m})$ fs pooled prevented fraction was $20 \%(95 \% \mathrm{CI} 1 \%$ to $38 \% ; p=0.04)$, with low quality evidence [24].

Urquhart et al. (2019) performed a network meta-analysis and concluded that $1.23 \%$ APF gel presented a double chance of arresting or reversing non-cavitated carious lesions on any coronal surfaces versus no treatment (moderate certainty) [2].

Studies conducted on professionally applied fluoride gel showed that caries-preventive fractions ranged between $23 \%$ and $60 \%$ (Table 1 ).

Table 1. Comparative data about professionally applied fluoride gel.

\begin{tabular}{|c|c|c|c|c|c|c|c|c|c|}
\hline Authors (Year) & $\begin{array}{l}\text { Study } \\
\text { Type }\end{array}$ & Country & Sample & Age & Comparison & Dentition & $\begin{array}{l}\text { Follow- } \\
\text { Up }\end{array}$ & Results & Reference \\
\hline $\begin{array}{c}\text { Van Rijkom et al. } \\
(2004)\end{array}$ & $\begin{array}{l}\text { double- } \\
\text { blind } \\
\text { RCT }\end{array}$ & $\begin{array}{c}\text { The Nether- } \\
\text { lands }\end{array}$ & 773 & 4-6 yr. & $\begin{array}{c}1 \% \text { NaF gel } \\
\text { applied } \\
\text { biannually in low } \\
\text { caries children vs. } \\
\text { placebo }\end{array}$ & $\begin{array}{c}\text { primary } \\
\text { and } \\
\text { permanent }\end{array}$ & 4 yr. & $\begin{array}{c}\text { PF for } \\
\mathrm{D}_{3} \mathrm{MFS}= \\
26 \% \text { PF for } \\
\mathrm{d}_{3} \mathrm{mfs}= \\
20 \%\end{array}$ & {$[25]$} \\
\hline $\begin{array}{l}\text { Truin \& van't Hof } \\
\qquad(2007)\end{array}$ & $\begin{array}{l}\text { double- } \\
\text { blind } \\
\text { RCT }\end{array}$ & $\begin{array}{c}\text { The Nether- } \\
\text { lands }\end{array}$ & 517 & $\begin{array}{l}\text { 9-11 } \\
\text { yr. }\end{array}$ & $\begin{array}{l}1 \% \text { NaF gel } \\
\text { applied } \\
\text { biannually in low } \\
\text { caries children vs. } \\
\text { placebo }\end{array}$ & permanent & 4 yr. & $P F=23 \%$ & [26] \\
\hline $\begin{array}{l}\text { Andruskeviciene } \\
\text { et al. (2008) }\end{array}$ & $\mathrm{RCT}$ & Lithuania & 411 & 3 yr. & $\begin{array}{l}\text { 1.23\% APF gel vs. } \\
\text { controlled } \\
\text { toothbrushing vs. } \\
\text { no treatment }\end{array}$ & primary & 3 yr. & $P F=60.1 \%$ & [27] \\
\hline
\end{tabular}

PF—-preventive fraction; RCT—randomized controlled trial.

Some studies reported non-significant differences between the test and control group, regarding professionally applied fluoride gel [28-30].

The European Academy of Paediatric Dentistry (EAPD) does not recommend the use of fluoride gels under the age of 6 years due to the danger of swallowing. In permanent dentition, EAPD moderately recommends 2 to 4 applications per year in appropriately sized trays, in an upright position, associated with suction devices during and after application to reduce swallowing, and interdiction to eat or drink 20-30 min after fluoride gel application [31].

The Australian Research Center for Population Oral Health (ARCPOH) recommended the use of high concentration fluoride gels (more than $1.5 \mathrm{mg} / \mathrm{g}$ fluoride ion) to be used for people aged 10 years or more who are at an elevated risk of developing caries [32].

Recently, atmospheric plasma activation of a hydroxyapatite enamel-like model proved to be almost twice as effective regarding fluoride incorporation from a $1450 \mathrm{ppm}$ fluoride gel (Fluor Protector, Ivoclar Vivadent, Schaan, Liechtenstein) than usual gel application. Furthermore, a certain antimicrobial and biofilm modulation was observed [33]. 


\subsection{Fluoride Varnishes}

There are three principal fluoride varnishes most commonly used: Duraphat (Colgate Oral Pharmaceuticals, Cologne, Germany) containing sodium fluoride with $2.26 \% \mathrm{~F}$ $(22,600 \mathrm{ppm})$, Fluor Protector (Ivoclar Vivadent, Schaan, Liechtenstein) containing 0.9\% difluorsilane with $0.1 \%$ [1000 ppm] F, and Bifluoride (Voco, Cuxhaven, Germany) containing sodium fluoride with $5.6 \% \mathrm{~F}[17,21,34,35]$. For a single application, 0.2 to $0.5 \mathrm{~mL}$ of fluoride varnish is usually used, and this amount contains approximately 5 to $10 \mathrm{mg}$ of total fluoride ion [16].

High-concentration fluoride varnish is applied by dental professionals directly onto the teeth and sets in a few seconds when it comes into contact with saliva $[16,17,36]$. Fluoride varnish is not intended to adhere permanently to the teeth; a small amount of varnish painted on the teeth maintains a highly concentrated topical fluoride in contact with the superficial layer of enamel for some time [17]. Through the varnish, the fluoride uptake increases in the superficial and deeper layers of the enamel [16]. Varnishes must be reapplied at regular intervals, effective caries protection requiring two applications per year [17].

Fluoride varnish has been frequently used as an anticaries agent in North America and Europe since the 1970s [22]. Several studies have reported that fluoride varnish and fluoride gel have a similar effect regarding caries prevention $[2,17,23,35]$.

According to U.S. Preventive Services Task Force, in-office application of fluoride varnish in children should start with the eruption of primary teeth [37].

There is no evidence in the specialty literature to point at professionally applied fluoride varnish as a risk factor for dental fluorosis, even among children younger than 6 years of age [17]. Single-dose applications of fluoride varnish are recommended for children. The total amount of fluoride swallowed is reduced by a proper application technique and is favored by the varnish capacity of wearing off the teeth over a period of hours [38]. Fluoride varnishes allow better control of patients' exposure to fluoride, less chair time being required than that needed for foams and gels [39]. No noticeable side effects were observed after using these products. Because asthmatic patients could have an allergic reaction, fluoride varnishes are contraindicated in these patients. Another side effect, especially noticed for Duraphat varnish, is the transient discoloration of the tooth, easily removed by professional brushing [23].

Manchanda et al. (2021) published a network meta-analysis about professionally and self-applied topical fluorides for early childhood caries (ECC) prevention, and they concluded that 3-month applications of $0.9 \%$ difluorosilane (DFS) and 6-month applications of $5 \%$ sodium fluoride varnish were effective in preventing caries occurrence in primary teeth in children younger than 6 years [40].

A meta-analysis performed by Gao et al. (2016) on four studies about the effect of $5 \%$ $\mathrm{NaF}$ varnish on early enamel caries showed that the overall percentage of remineralised enamel caries was 63.6\% (95\% CI: 36.0-91.2\%; $p<0.001)$ [41]. Moreover, Mishra et al. (2016) systematically reviewed the role of fluoride varnish in the prevention of early childhood caries. They found a caries preventive fraction of $6.4 \%$ to $30 \%$ when $1 \%$ varnish was applied, and $5 \%$ to $63 \%$ when the $5 \%$ concentration of fluoride was used [42].

In 2013, Marinho et al. performed a meta-analysis on topically-applied fluoride varnishes: 13 trials for permanent teeth and 10 trials for primary teeth. The pooled $\mathrm{D}(\mathrm{M}) \mathrm{FS}$ PF estimate comparing fluoride varnish with placebo or no treatment was $43 \%$ ( $95 \%$ confidence interval (CI) $30 \%$ to $57 \% ; p<0.0001)$. The pooled $\mathrm{d}(\mathrm{e} / \mathrm{m}) \mathrm{fs}$ PF estimate was $37 \%$ ( $95 \%$ CI $24 \%$ to $51 \%$; $p<0.0001$ ) [43]. Marinho et al. (2013) found that the caries protection benefit brought by fluoride varnish use is independent of baseline caries risk and severity, previous administration of fluorides, earlier prophylaxis, commonness of applications, and concentration of topical agent [44].

In their network meta-analysis, Urquhart et al. (2019) concluded that a combination of sealants and $5 \% \mathrm{NaF}$ varnish was the most effective in arresting or reversing lesions on occlusal surfaces versus non-treatment (RR, 3.35; 95\% CI, 2.42 to 4.64 , moderate cer- 
tainty) [2]. For non-cavitated carious lesions on smooth surfaces, this network meta-analysis demonstrated that $5 \% \mathrm{NaF}$ varnish application had a twice greater possibility of arresting or reversing enamel lesions vs. no treatment, while the association of the same fluoride varnish with resin infiltration increased this possibility to five times [2].

Many studies from the literature showed that professionally applied fluoride varnishes are effective for preventing dental caries in both dentitions (Table 2).

Table 2. Comparative data about professionally applied fluoride varnishes in RCTs.

\begin{tabular}{|c|c|c|c|c|c|c|c|c|}
\hline Authors (Year) & Country & Sample & Age & Comparison & Dentition & Follow-up & Results & Reference \\
\hline $\begin{array}{l}\text { Autio-Gold \& } \\
\text { Courts (2001) }\end{array}$ & USA & 142 & $3-5$ yr. & $\begin{array}{l}5 \% \mathrm{NaF} \text { varnish } \\
\text { vs. no treatment }\end{array}$ & primary & $9 \mathrm{mo}$ & $\begin{array}{c}\mathrm{dEs}=1.20 \text { vs. } 3.05 \\
\quad(p<0.001)\end{array}$ & [39] \\
\hline $\begin{array}{l}\text { Latifi-Xhemajli } \\
\text { et al. (2019) }\end{array}$ & Kosovo & 504 & 6-30 mo. & $\begin{array}{c}0.1 \% \mathrm{NaF} \\
\text { varnish applied } \\
4 \text { times/year vs. } \\
\text { no treatment }\end{array}$ & primary & $2 \mathrm{yr}$. & $\mathrm{PF}=49 \%$ & [45] \\
\hline $\begin{array}{l}\text { Turska-Szybka } \\
\text { et al. (2016) }\end{array}$ & Poland & 419 & $1-5 \mathrm{yr}$. & $\begin{array}{l}\text { resin infiltration } \\
\text { (RI) and fluoride } \\
\text { varnish (FV) vs. } \\
\text { fluoride varnish }\end{array}$ & primary & $1 \mathrm{yr}$. & $\begin{array}{l}92.1 \% \text { of the } \\
\text { infiltrated lesions (RI } \\
+ \text { FV) vs. } 70.6 \% \text { of the } \\
\text { FV lesions had not } \\
\text { progressed }(p<0.001)\end{array}$ & [46] \\
\hline $\begin{array}{l}\text { Honkala et al. } \\
\text { (2015) }\end{array}$ & Kuwait & 147 & 3 yr. & $\begin{array}{l}\text { sealants applied } \\
\text { to occlusal } \\
\text { surfaces of } \\
\text { primary molars } \\
\text { compared to } \\
\text { fluoride varnish } \\
\text { applications }\end{array}$ & primary & $1 \mathrm{yr}$. & $\begin{array}{l}\text { varnished surfaces } \\
\text { were significantly } \\
\text { more likely to } \\
\text { develop new caries } \\
\text { lesions than the } \\
\text { sealed ones } \\
(\mathrm{OR}=2.92 ; \\
95 \% \mathrm{CI}=1.82-4.71)\end{array}$ & [47] \\
\hline $\begin{array}{l}\text { Sonesson et al. } \\
\qquad(2020)\end{array}$ & Sweden & 182 & $12-18$ yr. & $\begin{array}{l}1.5 \% \text { ammonium } \\
\text { fluoride varnish } \\
\text { applied in } \\
\text { orthodontic } \\
\text { patients (TG) vs. } \\
\text { placebo (PG) }\end{array}$ & permanent & $1 \mathrm{yr}$. & $\begin{array}{c}\text { prevalence of WSLs } \\
\text { on subject after } \\
\text { debonding was } 41.8 \% \\
\text { (TG) vs. } 43.8 \%(\mathrm{PG}) \\
\text { the no. of patients } \\
\text { with more severe } \\
\text { lesions (score } 3+4) \\
\text { was higher in PG } \\
(p<0.05)\end{array}$ & [48] \\
\hline $\begin{array}{l}\text { Xhemnica et al. } \\
\text { (2008) }\end{array}$ & Albania & 92 & $11.7 \mathrm{yr}$. & $\begin{array}{l}5 \% \mathrm{NaF} \text { varnish } \\
\text { vs. no treatment }\end{array}$ & permanent & $7 \mathrm{mo}$ & $\begin{array}{c}\mathrm{dEs}=0.87 \text { vs. } 3.90 \\
(p<0.05)\end{array}$ & [49] \\
\hline $\begin{array}{l}\text { Oliveira et al. } \\
\text { (2014) }\end{array}$ & Brazil & 200 & $1-4 \mathrm{yr}$. & $\begin{array}{l}5 \% \mathrm{NaF} \text { varnish } \\
\text { vs. placebo } \\
\text { varnish }\end{array}$ & primary & $2 \mathrm{yr}$. & $\mathrm{PF}=28 \%$ & [50] \\
\hline $\begin{array}{l}\text { Arruda et al. } \\
\quad(2012)\end{array}$ & Brazil & 379 & 7-14 yr. & $\begin{array}{l}5 \% \mathrm{NaF} \text { varnish } \\
\text { vs. placebo }\end{array}$ & permanent & $1 \mathrm{yr}$. & $\mathrm{PF}=40 \%$ & [51] \\
\hline
\end{tabular}

dEs—decayed surfaces with initial enamel lesions; WSL—white spot lesions; PF—preventive fraction.

All these RCT [39,45-51] studies and meta-analyses concluded that fluoride varnishes exhibited an important caries-inhibiting effect in both permanent and primary dentitions, with reductions in caries ranging from 28 to $70 \%$.

Despite clinically proven efficacy, professionally applied fluoride varnish is not widely used in the world [52]. In countries with community water fluoridation, such as the USA and Australia, fluoride varnish is recommended only for patients with increased caries risk, but in those countries with no water fluoridation or a small concentration of fluoride in drinking water (e.g., England, Scotland) fluoride varnish is indicated for caries prevention in all children and adolescents [52]. Furthermore, a recent systematic review and metaanalysis performed by Yu et al. (2021) showed that fluoride varnish did not add significant caries-preventive benefits for children under 8 years old using regular fluoride toothpaste with $\geq 1000$ ppm (low to moderate certainty evidence) [53] 
Ferreira et al. conducted an RCT regarding the therapeutic effect of two fluoride varnishes on white spot lesions, finding a similar effect for both materials after four applications. A preventive fraction of $80 \%$ was found, associated with a reduction in the magnitude of WSL [54]. Another Brazilian study found an overall preventive fraction of $45.7 \%$ for three fluoride varnishes [55]. Baik et al. underlined the importance of risk assessment for the application of fluoride varnish while confirming the effectiveness of these materials in preventing occlusal caries in moderate-high caries risk [56]. These authors recommend two to four applications per year of fluoride varnish [56]. Additonally, Baik et al. could not establish which intervention (pit and fissure sealants vs. fluoride varnish) had better results, in agreement with Kashbour et al. [57] and Deery [58]. Among professionally applied fluoride products, fluoride varnish is the most adequate regarding safety and acceptability, as well as regarding caries prevention in high-risk children and adolescents, orthodontic patients, and the elderly [59].

Some studies proved that professionally applied fluorides (such as varnishes) are more effective in preventing caries on smooth surfaces than occlusal surfaces $[23,60]$.

According to the American Dental Association (ADA), professionally applied fluorides, depending on caries risk and age, are synthetized in Table 3.

Table 3. Clinical recommendations for the professional application of fluoride varnish and gel.

\begin{tabular}{|c|c|c|c|}
\hline Caries Risk & Younger than 6 Years & 6-18 Years & Older than 18 Years \\
\hline Low & \multicolumn{3}{|c|}{ No additional benefit } \\
\hline Moderate & Fluoride varnish at 6 months interval & Fluoride va & 6 months interval \\
\hline High & Fluoride varnish at 3-6 months interval & Fluoride var & -6 months interval \\
\hline
\end{tabular}

The EAPD moderately recommends $2-4$ applications of fluoride varnishes for the prevention of caries in both dentitions, especially in children of increased risk of caries development, as well as in children with special oral health care needs, orthodontic patients, or during sensible periods such as tooth eruption [31]. According to the EAPD [31] and ADA [37], fluoride varnish is the only topical agent to be used in preschool. Australia's $\mathrm{ARCPOH}$ recommends the application of fluoride varnish in patients with an elevated risk of developing caries, including children under the age of 10 years [32].

\subsection{Fluoride Foams}

Neutral or acidulated fluoride foam is a professional option instead of gel but is less studied in clinical trials. The APF foam has the same fluoride concentration $(12,300 \mathrm{ppm})$ and $\mathrm{pH}$ as APF gels [61].

In the dental office, fluoride foam is usually applied in a trimmed, sponge-lined tray, which is bitten by the patient for $4 \mathrm{~min}$. Compared with the fluoride gel, only one-fifth of the amount by weight is needed for proper coverage of the teeth [62]. Australian ARCPOH finds no evidence to support the use of foam [32].

Data showed that fluoride foams are more effective in permanent dentition (Table 4).

Table 4. Comparative data from clinical trials about professionally applied fluoride foams applied in trays.

\begin{tabular}{ccccccccc}
\hline Authors (Year) & Country & Sample & Age & Comparison & Dentition & Follow-Up & Results & Reference \\
\hline Jiang et al. (2005) & China & 392 & 3-4 yr. & $\begin{array}{c}1.23 \% \text { APF foam applied } \\
\text { bi-annual vs. placebo }\end{array}$ & primary & 2 yr. & PF = 24.2\% & {$[62]$} \\
\hline Jiang et al. (2013) & China & 100 & $10-20$ yr. & $\begin{array}{c}1.23 \% \text { APF applied } \\
\text { bi-monthly in patients } \\
\text { with fixed orthodontic } \\
\text { appliances vs. placebo }\end{array}$ & permanent & 18 mo. & PF $=76 \%$ & {$[63]$} \\
\hline
\end{tabular}




\subsection{Fluoride Mouthrinse}

The fluoride mouthrinses may contain two fluorides: APF and stannous fluoride. These can be mixed or used concurrently. The fluoride concentrations of in-office rinses are much lower compared with APF gel or varnish (1500-3000 ppm vs. 12,300 ppm/22,600 ppm).

Compared to other professionally applied fluorides, the mouthrinses can be more easily swallowed, and, consequently, there is a greater risk for ingestion. The use of fluoride mouthrinses is contraindicated in young children because acute fluoride toxicity could result if they were swallowed.

Furthermore, these rinses have a sharp, metallic taste and are not well tolerated by patients. For all these reasons, professional fluoride rinses are not recommended for the prevention of dental caries because other effective in-office fluoride products are readily available [23].

Fluoride mouthrinses with lower fluoride concentrations were used for decades in school-based preventive programs worldwide and home use for subjects at high caries risk, e.g., patients with fixed orthodontic appliances [64]. The EAPD underlines the need for parental or educators' supervision for a more efficacious effect and the need to restrict eating or drinking for $30 \mathrm{~min}$ after rinsing [31].

\subsection{Fluoride-Containing Prophylaxis Paste}

Dental prophylaxis maneuvers usually imply the use of paste containing fluoride. This is an abrasive paste, which may contain fluoride in a concentration between 4000 and $20,000 \mathrm{ppm}$. Fluoride from prophylaxis paste might restore the fluoride concentration in the superficial layer of enamel but it cannot substitute fluoride gel or varnish regarding the prevention of dental caries in persons at high risk [22].

The solitary use of fluoride prophylaxis paste is not considered by the US Food and Drug Administration (FDA) or ADA as an effective method for preventing dental caries $[22,37]$.

Several studies showed that there were no statistically significant differences in caries experience reduction between patients who received cleaning before the professional application of fluoride and those patients who did not receive a cleaning (Johnston \& Lewis (1995) and Ripa et al. (1984) cited by [24]).

\subsection{Discussion}

Fluoride topical products contribute to the prevention of dental caries to varying degrees depending on the pharmaceutical form used. Mouthrinses and foams seem to be least effective and are more frequently and easily related to acute overdosage. Fluoride gels can be associated with clinical precautions and over ingestion symptoms, leaving fluoride varnishes as the optimal solution for topical fluoride treatments due to its high fluoride concentration and long-time wearing off the teeth.

Professionally applied topical fluoride usage must be correlated with the patient's age, caries risk, systemic input of fluoride, and, also, with the fluoride concentration of homeuse toothpaste. There is a difference regarding the age threshold for the use of fluoride gels, with the ADA and EAPD setting it at 6 years, while Australia's ARCPOH recommends gel applications after the age of 10 . There is a common point of view regarding the use of professionally applied fluorides in high caries risk patients. The total amount of fluoride ingested (systemic and during toothbrushing) is important for avoiding dental fluorosis, especially in small children who swallow higher percentages of the used toothpaste.

Future research regarding the prevention of dental caries is oriented towards the improvement of antimicrobial properties of restorative materials, combining this well-known inorganic, monoatomic anion with other antimicrobial substances (e.g., chlorhexidine, quaternary ammonium compounds), development of chemical modifications enhancing drug release, and surface modification for an antimicrobial and biofilm modulation effect. A comparative study on the costs of dental decay prevention using professionally 
applied fluorides and/or community water fluoridation in various countries should also be performed.

The limitations of this study are related to the extension of the literature search, as well as related to characteristics of RCTs, with some of them presenting unclear randomization methodology, a reduced number of subjects, or a short follow-up period.

\title{
4. Conclusions
}

Professionally applied fluorides are useful and recommended for caries prevention in patients with an elevated risk of dental decay, especially in patients with active caries on smooth tooth surfaces, in children with special oral health needs, or orthodontic patients.

Prevention of dental caries in temporary and permanent dentition can be done effectively using APF gel or fluorinated varnishes. For children under the age of 6 , only $2.26 \%$ fluoride varnish is recommended.

The European Academy of Pediatric Dentistry and the American Dental Association have similar recommendations regarding topical fluoride applications based on caries-risk assessment. Community water fluoridation is seen by both organizations as an important element in a complex approach of caries prevention, to which is added the use of topical fluoride in relation to caries-risk assessment. Australian authorities recommend the use of local fluoridation for patients at high risk of caries development, using gels for children aged 10 years and older, while fluorinated varnishes are recommended for children under 10.

\begin{abstract}
Author Contributions: Conceptualization A.M., A.-M.H., M.-R.P., A.-T.F. and C.F.; methodology A.M., A.-T.F., M.I. and C.F.; validation A.M., A.-M.H., M.-R.P., M.I. and C.F.; investigation A.M., M.-R.P., M.I., A.-T.F. and C.F.; writing-original draft preparation A.M., A.-M.H., A.-T.F., M.I. and C.F.; writing-review and editing A.M., A.-M.H., M.-R.P., A.-T.F. and C.F. All authors have read and agreed to the published version of the manuscript.
\end{abstract}

Funding: This study was supported by UEFISCDI through Grant no. 271/2020 “Cold plasma for fluoride retention improvement and biofilm modulation in dental application", project code: PN-III-P2-2.1-PED-2019-4569.

Institutional Review Board Statement: Not applicable.

Informed Consent Statement: Not applicable.

Conflicts of Interest: The authors declare no conflict of interest.

\section{References}

1. Petersen, P.E. Sociobehavioural risk factors in dental caries-international perspectives. Community Dent. Oral Epidemiol. 2005, 33, 274-279. [CrossRef] [PubMed]

2. Urquhart, O.; Tampi, M.P.; Pilcher, L.; Slayton, R.L.; Araujo, M.W.B.; Fontana, M.; Guzmán-Armstrong, S.; Nascimento, M.M.; Nový, B.B.; Tinanoff, N.; et al. Nonrestorative Treatments for Caries: Systematic Review and Network Meta-analysis. J. Dent. Res. 2019, 98, 14-26. [CrossRef] [PubMed]

3. Ahovuo-Saloranta, A.; Forss, H.; Hiiri, A.; Nordblad, A.; Mäkelä, M. Pit and fissure sealants versus fluoride varnishes for preventing dental decay in the permanent teeth of children and adolescents. Cochrane Database Syst. Rev. 2016, 1, CD003067. [CrossRef]

4. American Academy of Pediatric Dentistry. Fluoride Therapy; The Reference Manual of Pediatric Dentistry, Chicago, III. American Academy of Pediatric Dentistry: Chicago, IL, USA, 2020; pp. 288-291. Available online: https://www.aapd.org/media/Policies_ Guidelines/BP_FluorideTherapy.pdf (accessed on 1 October 2021).

5. Zampetti, P.; Scribante, A. Historical and bibliometric notes on the use of fluoride in caries prevention. Eur. J. Paediatr. Dent. 2020, 21, 148-152. [CrossRef] [PubMed]

6. Desai, H.; Stewart, C.A.; Finer, Y. Minimally invasive therapies for the management of dental caries-A literature review. Dent. J. 2021, 9, 147. [CrossRef]

7. Holban, A.M.; Farcașiu, C.; Andrei, O.C.; Grumezescu, A.M.; Farcașiu, A.T. Surface modification to modulate microbial biofilmsApplications in dental medicine. Materials 2021, 14, 6994. [CrossRef]

8. Available online: https://ec.europa.eu/health/sites/default/files/endocrine_disruptors/docs/cosmetic_1223_2009_regulation_ en.pdf (accessed on 1 November 2021).

9. Available online: https://ec.europa.eu/health/scientific_committees/opinions_layman/fluoridation/en/ (accessed on 10 December 2021). 
10. Ferro, R.; Besostri, A.; Giuca, M.R.; Docimo, R.; Gatto, R.; Marzo, G. The Italian perspective on fluoride intake in children and adolescents. Eur. J. Paediatr. Dent. 2014, 15, 55-58.

11. Hong, L.; Levy, S.M.; Broffitt, B.; Warren, J.J.; Kanellis, M.J.; Wefel, J.S.; Dawson, D. Timing of fluoride intake in relation to development of fluorosis on maxillary central incisors. Community Dent. Oral Epidemiol. 2006, 34, 299-309. [CrossRef] [PubMed]

12. Whitford, G.M. Acute toxicity of ingested fluoride. Monogr. Oral Sci. 2011, 2, 66-80. [CrossRef]

13. Scientific Committee on Health and Environmental Risks of the European Union. Critical Review of Any New Evidence on the Hazard Profile, Health Effects, and Human Exposure to Fluoride and the Fluoridating Agents of Drinking Water; European CommissionScientific Committee on Health and Environmental Risks: Brussels, Belgium, 2011; pp. 13-15. Available online: https:/ / ec.europa. eu/health/scientific_committees/environmental_risks/docs/scher_o_139.pdf (accessed on 5 November 2021).

14. Hong, L.; Levy, S.M.; Warren, J.J.; Broffitt, B.; Cavanaugh, J. Fluoride intake levels in relation to fluorosis development in permanent maxillary central incisors and first molars. Caries Res. 2006, 40, 494-500. [CrossRef]

15. Wright, T.J.; Hanson, N.; Ristic, H.; Whall, C.W.; Estrich, C.G.; Zentz, R.R. Fluoride toothpaste efficacy and safety in children younger than 6 years: A systematic review. J. Am. Dent. Assoc. 2014, 145, 182-189. [CrossRef] [PubMed]

16. Adair, S.M. Evidence-based use of fluoride in contemporary pediatric dental practice. Pediatr. Dent. 2006, 28, 133-134. [PubMed]

17. Centers for Disease Control and Prevention. Other Fluoride Products. U.S. Department of Health and Human Services. Available online: https: / / www.cdc.gov / fluoridation/basics / fluoride-products.html (accessed on 1 October 2021).

18. American Dental Association Council on Scientific Affairs. Professionally applied topical fluoride: Evidence-based clinical recommendations. JADA 2006, 137, 1151-1159. [CrossRef]

19. Buzalaf, M.A.; Pessan, J.P.; Honório, H.M.; Ten Cate, J.M. Mechanism of action of fluoride for caries control. Monogr. Oral Sci. 2011, 22, 97-114. [CrossRef]

20. Rozier, R.G.; Adair, S.; Graham, F.; Iafolla, T.; Kingman, A.; Kohn, W.; Krol, D.; Levy, S.; Pollick, H.; Whitford, G.; et al. Evidencebased clinical recommendations on the prescription of dietary fluoride supplements for caries prevention: A report of the American Dental Association Council on Scientific Affairs. J. Am. Dent. Assoc. 2010, 141, 1480-1489. [CrossRef]

21. Brudevold, F.; Savory, A.; Gardner, D.E.; Spinelli, M.; Speirs, R. A study of acidulated fluoride solutions. I. In vitro effects on enamel. Arch. Oral Biol. 1963, 8, 167-177. [CrossRef]

22. Center for Disease Control and Prevention. Recommendations for using fluoride to prevent and control dental caries in the United States. MMWR Recomm. Rep. 2001, 50, 1-42.

23. Hawkins, R.; Locker, D.; Noble, J. Prevention. Part 7: Professionally applied topical fluorides for caries prevention. Br. Dent. J. 2003, 195, 313-317. [CrossRef] [PubMed]

24. Marinho, V.C.C.; Worthinghton, H.V.; Walsh, T.; Chong, L.Y. Fluoride gels for preventing dental caries in children and adolescents. Cochrane Databases Syst. Rev. 2015, 6, CD002280. [CrossRef]

25. Van Rijkom, H.M.; Truin, G.J.; Van't Hof, M.A. Caries-inhibiting effect of professional fluoride gel application in low-caries children initially aged 4.5-6.5 years. Caries Res. 2004, 38, 115-123. [CrossRef]

26. Truin, G.J.; Van't Hof, M. The effect of fluoride gel on incipient carious lesions in a low-caries risk child population. Community Dent. Oral Epidemiol. 2007, 35, 250-254. [CrossRef] [PubMed]

27. Andruskeviciene, V.; Milciuviene, S.; Bendoraitiene, E.; Saldunaite, K.; Vasiliauskiene, I.; Slabsinskiene, E.; Narbutaite, J. Oral health status and effectiveness of caries prevention programme in kindergartens in Kaunas city (Lithuania). Oral Health Prev. Dent. 2008, 6, 343-348. [PubMed]

28. Ferreira, M.A.; Latorre, M.; Rodrigues, C.S.; Lima, K.C. Effect of regular fluoride gel application on incipient carious lesions. Oral Health Prev. Dent. 2005, 3, 141-149. [PubMed]

29. Ersin, N.K.; Eden, E.; Eronat, N.; Totu, F.I.; Ates, M. Effectiveness of 2-year application of school-based chlorhexidine varnish, sodium fluoride gel, and dental health education programs in high-risk adolescents. Quintessence Int. 2008, 39, e45-e51.

30. Bonow, M.L.M.; Azevedo, M.S.; Goettems, M.L.; Rodrigues, C.R.M.D. Efficacy of $1.23 \%$ APF gel applications on incipient carious lesions: A double-blind randomized clinical trial. Braz. Oral Res. 2013, 27, 279-285. [CrossRef]

31. Toumba, K.J.; Twetman, S.; Splieth, C.; Parnell, C.; Van Loveren, C.; Lygidakis, N.A. Guidelines on the use of fluoride for caries prevention in children: An updated EAPD policy document. Eur. Arch. Paediatr. Dent. 2019, 20, 507-516. [CrossRef]

32. Do, L.G. Guidelines for use of fluorides in Australia: Update 2019. Aust. Dent. J. 2020, 65, 30-38. [CrossRef]

33. Zarif, M.E.; Yehia, S.A.; Biță, B.; Sătulu, V.; Vizireanu, S.; Dinescu, G.; Holban, A.M.; Marinescu, F.; Andronescu, E.; Grumezescu, A.M.; et al. Atmospheric pressure plasma activation of hydroxyapatite to improve fluoride incorporation and modulate bacterial biofilm. Int. J. Mol. Sci. 2021, 22, 13103. [CrossRef]

34. Petersson, L.G.; Twetman, S.; Dahlgren, L.; Norlund, A.; Holm, A.-K.; Nordenram, G.; Lagerlöf, F.; Söder, B.; Källestål, C.; Mejare, I.; et al. Professional fluoride varnish treatment for caries control: A systematic review of clinical trials. Acta Odontol. Scand. 2004, 62, 170-176. [CrossRef]

35. Weyant, R.J.; Tracy, S.L.; Anselmo, T.T.; Beltrán-Aguilar, E.; Donly, K.; Frese, W.; Hujoel, P.; Iafolla, T.; Kohn, W.; Kumar, J. Topical fluoride for caries prevention: Executive summary of the updated clinical recommendations and supporting systematic review. $J$. Am. Dent. Assoc. 2013, 144, 1279-1291. [CrossRef]

36. Clark, M.B.; Slayton, R.L. Fluoride use in caries prevention in the primary care setting. Pediatrics 2014, 134, 626-633. [CrossRef] [PubMed] 
37. Moyer, V.A. Prevention of dental caries in children from birth through age 5 years: US Preventive Services Task Force Recommendation Statement. Pediatrics 2014, 133, 1102-1111. [CrossRef] [PubMed]

38. Levy, S.M. An update on fluorides and fluorosis. J. Can. Dent. Assoc. 2003, 69, 286-291.

39. Autio-Gold, J.T.; Courts, F. Assessing the effect of fluoride varnish on enamel carious lesions in the primary dentition. J. Am. Dent. Assoc. 2001, 132, 1247-1253. [CrossRef] [PubMed]

40. Manchanda, S.; Sardana, D.; Liu, P.; Lee, G.H.; Li, K.Y.; Lo, E.C.; Yiu, C.K. Topical fluoride to prevent early childhood caries: Systematic review with network meta-analysis. J. Dent. 2021, 12, 103885. [CrossRef]

41. Gao, S.S.; Zhang, S.; Mei, M.L.; Lo, E.C.; Chu, C.H. Caries remineralisation and arresting effect in children by professionally applied fluoride treatment-A systematic review. BMC Oral Health 2016, 16, 12. [CrossRef]

42. Mishra, P.; Fareed, N.; Battur, H.; Khanagar, S.; Bhat, M.A.; Palaniswamy, J. Role of fluoride varnish in preventing early childhood caries: A systematic review. Dent. Res. J. (Isfahan) 2017, 14, 169-176. [CrossRef] [PubMed]

43. Marinho, V.C.C.; Worthinghton, H.V.; Walsh, T.; Clarkson, J.E. Fluoride varnishes for preventing dental caries in children and adolescents. Cochrane Database Syst. Rev. 2013, 11, CD002279. [CrossRef] [PubMed]

44. Bonetti, D.; Clarkson, J.E. Fluoride varnish for caries prevention: Efficacy and implementation. Caries Res. 2016, 50 (Suppl. S1), 45-49. [CrossRef]

45. Latifi-Xhemajli, B.; Begati, A.; Veronneau, J.; Kutllovici, T.; Rexhepi, A. Effectiveness of fluoride varnish four times a year in preventing caries in primary dentition: A 2 year randomized controlled trial. Community Dent. Health 2019, 36, 190-194. [CrossRef]

46. Turska-Szybka, A.; Gozdowski, D.; Mierzwinska-Nastalska, E.; Olczak-Kowalczyk, D. Randomised clinical trial on resin infiltration and fluoride varnish vs fluoride varnish treatment only of smooth-surface early caries lesions in deciduous teeth. Oral Health Prev. Dent. 2016, 14, 485-491. [CrossRef]

47. Honkala, S.; ElSalhy, M.; Shyama, M.; Al-Mutawa, S.A.; Boodai, H.; Honkala, E. Sealant versus fluoride in primary molars of kindergarten children regularly receiving fluoride varnish: One-year randomized clinical trial follow-up. Caries Res. 2015, 49, 458-466. [CrossRef]

48. Sonesson, M.; Brechter, A.; Abdulraheem, S.; Lindman, R.; Twetman, S. Fluoride varnish for prevention white spot lesions during orthodontic treatment with fixed appliances: A randomized controlled trial. Eur. J. Orthod. 2020, 42, 326-330. [CrossRef]

49. Xhemnica, L.; Sulo, D.; Rroço, R.; Hysi, D. Fluoride varnish application: A new prophylactic method in Albania. Effect on enamel carious lesions in permanent dentition. Eur. J. Paediatr. Dent. 2008, 9, 93-96. [PubMed]

50. Oliveira, B.H.; Salazar, M.; Carvalho, D.M.; Falcão, A.; Campos, K.; Nadanovsky, P. Biannual fluoride varnish applications and caries incidence in preschoolers: A 24-month follow-up randomized placebo-controlled clinical trial. Caries Res. 2014, 48, 228-236. [CrossRef] [PubMed]

51. Arruda, A.O.; Kannan, R.S.; Inglehart, M.R.; Rezende, C.T.; Sohn, W. Effect of $5 \%$ fluoride varnish application on caries among school children in rural Brazil: A randomized controlled trial. Community Dent. Oral Epidemiol. 2012, 40, 267-276. [CrossRef] [PubMed]

52. O'Mullane, D.; Baez, R.; Jones, S.; Lennon, M.; Petersen, P.; Rugg-Gun, A.; Whelton, H.; Whitford, G.M. Fluoride and oral health. Community Dent. Health 2016, 33, 69-99. [CrossRef]

53. Yu, L.; Yu, X.; Li, Y.; Yang, F.; Hong, J.; Qin, D.; Song, G.; Hua, F. The additional benefit of professional fluoride application for children as an adjunct to regular fluoride toothpaste: A systematic review and meta-analysis. Clin. Oral Investig. 2021, 25, 3409-3419. [CrossRef]

54. Ferreira, J.M.S.; Aragão, A.K.R.; Rosa, A.D.B.; Sampaio, F.C.; Menezes, V.A. Therapeutic effect of two fluoride varnishes on white spot lesions: A randomized clinical trial. Braz. Oral Res. 2009, 23, 446-451. [CrossRef]

55. Almeida, M.Q.; Costa, O.X.I.; Ferreira, J.M.S.; Menezes, V.A.; Leal, R.B.; Sampaio, F.C. Therapeutic potential of Brazilian fluoride varnishes: An in vivo study. Braz. Dent. J. 2011, 22, 193-197. [CrossRef]

56. Baik, A.; Alamoudi, N.; El-Housseiny, A.; Altuwirqi, A. Fluoride Varnishes for Preventing Occlusal Dental Caries: A Review. Dent. J. 2021, 9, 64. [CrossRef] [PubMed]

57. Kashbour, W.; Gupta, P.; Worthington, H.V.; Boyers, D. Pit and fissure sealants versus fluoride varnishes for preventing dental decay in the permanent teeth of children and adolescents. Cochrane Database Syst. Rev. 2020, 11, CD003067. [CrossRef] [PubMed]

58. Deery, C. Fissure seal or fluoride varnish? Evid. Based Dent. 2016, 17, 77-78. [CrossRef] [PubMed]

59. Quock, R.L.; Warren-Morris, D.P. Fluoride varnish: The top choice for professionally applied fluoride. J. Mich. Dent. Assoc. 2011, 93, 42-48.

60. Prabhakar, A.; Dahake, P.T.; Raju, O.; Basappa, N. Fluoride: Is It Worth to be added in Pit and Fissure Sealants? Int. J. Clin. Pediatr. Dent. 2012, 5, 1-5. [CrossRef]

61. Twetman, S.; Keller, M.K. Fluoride rinses, gels and foams: An update of controlled clinical trials. Caries Res. 2016, 50 (Suppl. S1), 38-44. [CrossRef]

62. Jiang, H.; Bian, Z.; Tai, B.J.; Du, M.Q.; Peng, B. The effect of bi-annual professional application of APF foam on dental caries increment in primary teeth: 24-month clinical trial. J. Dent. Res. 2005, 84, 265-268. [CrossRef]

63. Jiang, H.; Hua, F.; Yao, L.; Tai, B.; Du, M. Effect of 1.23\% acidulated phosphate fluoride foam on white spot lesions in orthodontic patients: A randomized trial. Pediatr. Dent. 2013, 35, 275-278.

64. Rugg-Gunn, A.; Bánóczy, J. Fluoride toothpastes and fluoride mouthrinses for home use. Acta Med. Acad. 2013, 42, 168-178. [CrossRef] 